\title{
FLOOD VULNERABILITY AND INCIDENCE IN IBAJI LOCAL GOVERNMENT AREA OF KOGI STATE, NIGERIA
}

\author{
Andrew Ekojoka AJODO \\ Nigerian Defence Academy, Department of Geography, Postgraduate School Kaduna, Nigeria, \\ e-mail: ajodoandrew@gmail.com \\ Raphael OLAWEPO * \\ Department of Geography and Environmental Management, University of Ilorin, Ilorin Nigeria, \\ e-mail: ralfabbey@yahoo.com
}

Citation: Ajodo, A.E, Olawepo, R. (2021). Flood Vulnerability and Incidence in Ibaji Local Government Area of Kogi State, Nigeria. Analele Universității din Oradea, Seria Geografie, 31(1), 57-67. https://doi.org/10.30892/auog.311107-854

\begin{abstract}
This study is aimed at assessing flood vulnerability of Ibaji LGA of Kogi state, Nigeria. The factors considered in this research include socioeconomic activities, rainfall characteristics, land-use pattern, drainage density, slope, soil, and elevation. The Analytical Hierarchy Process (AHP) was used to establish the relationship between flood causative factors and their role in the occurrence as well as the vulnerability of communities within the study area. Each factor was assigned weight depending on the perceived role in the occurrence of flood within the study area. The factors considered in this research and their cumulative weights are rainfall (24.4\%), Drainage Density (17.9\%), Slope (18.5\%), Elevation (17.4\%), Land Use (11.8\%) and soil (9.9\%). The results of this study suggest that no single factor is responsible for the occurrence of flood in the study area, a combination of the factors assessed are responsible for the occurrence of flood. The degree of susceptibility of communities to flood in the study area varies among communities dependent on the factors that predominate within the community.
\end{abstract}

Key words: drainage, disaster, environment, hazards

* $\quad * \quad * \quad * \quad * \quad *$

\section{INTRODUCTION}

Floods are a natural phenomenon or occurrence in which dry lands are submerged with water. Flooding is a temporary condition of widespread submergence of dry lands from runoff of inland or tidal waters or from unusual and rapid accumulation of runoff (Jeb and Aggarwal, 2008). Flooding is characterized by the accumulation of excess water which rises to overflow land which is not normally inundated (Mukhopadhyay, 2010). Flood is defined as the flow of water above a channels carrying capacity (Olajuyigbe et al., 2012).

According to Disaster Management Support Group (DMSG, 2001), floods are among the most devastating hazards, resulting in significant economic and social losses. In the last three 
decades, flood impacts have increased significantly, resulting in loss of lives and properties in Nigeria. There has been an increased frequency of floods occurrence, as a result, thousands of people have been affected by flood with their agricultural field and residential areas affected (United Nation 2003). Globally, flood disasters are said to have devastating effect on economic development, health, agriculture, social and human life (Marcellinus and Joseph, 2015).

The increasing number of flood incidences coupled with the constrained sustainable development caused by flood in Nigeria suggests that much of what is known regarding floods is deficient on remedies (World Bank, 2013). Flooding occurs in Nigeria every year and potential risk exists in the low lying flood plains of River Niger, human encroachment into areas liable to flood is growing rapidly due to the huge natural resources and agricultural potentials found in such areas (Jeb and Aggarwal, 2008).

Flood affects various aspects of man's environment; this includes his economic activities, settlements and lifestyle. Several threats to livelihoods ranging from the physical threats to social and economic threats exist. Flooding also causes land pollution, epidemics and infections. A lot of emotional and social costs have been intricate to flooded regions. These costs include: the loss of personal valuables, displacement from homes, and the insecurity caused by the experience. Furthermore, in Ibaji Local Government Area of Kogi State, flooding has made the people to suffer untold hardships resulting from economic and social losses.

The aim of this study is two folds. First, it is to assess flood vulnerability and incidence in Ibaji Local Government Area of Kogi State, Nigeria; and second, it focuses on examining the factors responsible for flood occurrence in the study area with a view to proffer appropriate solution for future adherence.

Flood incidence of varying magnitude occurs yearly along River Niger which is as a result of the runoff on River Niger during the peak of the rainy season resulting in loss of valuable properties, destruction of infrastructure, livestock and crops. It is therefore important to assess the extent of vulnerability of communities that lies within this basin using Geographic Information System (GIS) and remote sensing as tools for this analysis (Herman, 2010).

\section{The Study Area}

Ibaji Local Government Area (LGA) is located south of Kogi state. The area has a land mass of about 1,377 square kilometres. It lies between Latitude: $06^{\circ} 52^{\prime} 00^{\prime \prime} \mathrm{N}$ and $06^{\circ} 87^{\prime} 00^{\prime \prime} \mathrm{N}$ of the equator, and Longitude $06^{\circ} 48^{\prime} 00^{\prime \prime} \mathrm{E}$ and $06^{\circ} 80^{\prime} 00^{\prime \prime} \mathrm{E}$ of Greenwich meridian (Kosema, 2007; (Figures 1 and 2). Ibaji LGA has a tropical climate that has two seasons namely wet and dry seasons. The wet season starts from the month of April and ends in October, while the dry season starts from November and continues till March. The soils are characterized by a sandy texture overlying a weakly structured clay accumulation (Atoyebi, 2013). The flood plains (of the Rivers Niger and Benue valleys) in Ibaji are made up of hydromorphic soils that contain mixture of coarse alluvial and colluvial deposits (Oriola, 1994).

\section{Conceptual Framework and Literature Review}

According to UNISDR 2009, there is no single approach to disaster management. There are a number of methodologies and strategies adopted in other to achieve environmental sustainability. To arrive at these strategies, there is a need to thoroughly consider the factors responsible for flood within the local context. Identification of flood hazard goes beyond identifying treats and the extent of damage caused by floods but also identifying the factors responsible for the increasing flood incidence, the vulnerability of the community and the strategies to mitigate the adverse effects of the flood.

Floods are hydrological phenomena that result from a complex sequence of natural events prediction of such events is possible only when there is an adequate understanding of causes of flood events in a basin. The frequency, duration and magnitude of floods are determined by several 
factors. Flooding results from a number of factors among which are meteorological factors, geomorphic factors and anthropogenic factors (Ward, 1978).

Karmakar et al. (2010) define flood risk as the consequence of flood hazards, (the physical and statistical aspects of the actual flooding for example, the extent and depth of inundation) and the vulnerability (the exposure of people and assets to floods and the susceptibility of the elements). Flood risk is thus a combination of hazard (potential damage), vulnerability (probability of flooding occurrence) and impact of exposure.

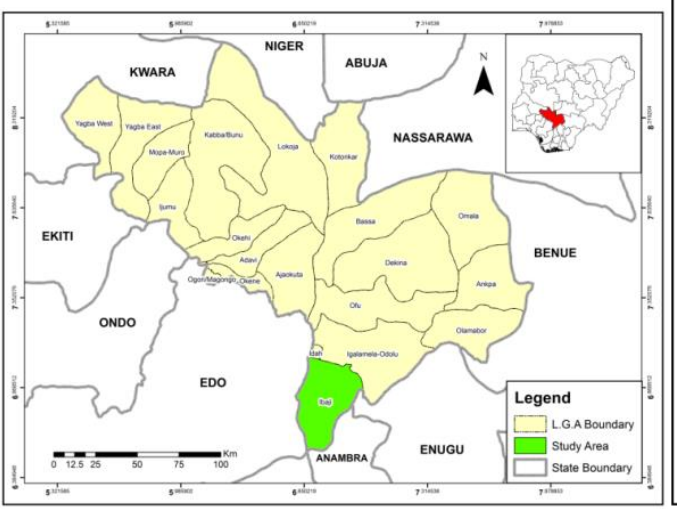

Figure 1. Map of Kogi State showing Ibaji LGA Source: Ministry of Environment Kogi State

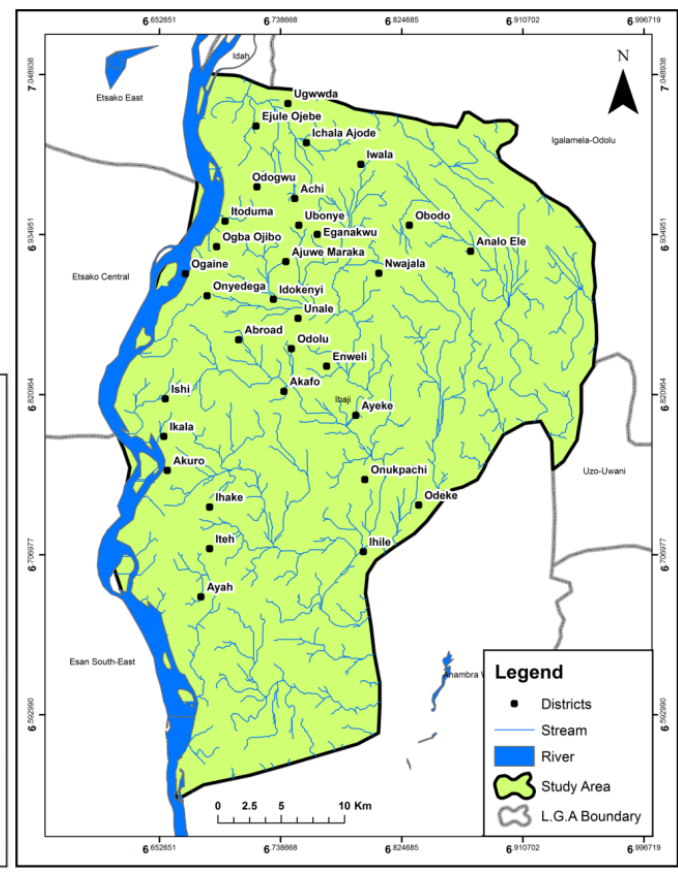

Figure 2. Map showing Drainage Pattern in Ibaji Source: Ministry of Environment Kogi State

According to the United Nations Office of Disaster Risk Reduction (UNISDR), risk is the likelihood of an event and its consequences (UNISDR, 2009). Flood risk is the product of the flood hazards, the vulnerability and the exposure (UNISDR, 2009). Flood risk basically revolves around two main elements; hazard and vulnerability (Ward et al., 2011; De Moel et al., 2012; Kreibich et al., 2010). On the other hand, for effective flood riak analysis, it is important to understand the degree of susceptibility of elements to flood hazards. While the concept of vulnerability is still been studied, it remains an important element in risk analysis and disaster control measures (Birkmann, 2006; Herman, 2009).

Hazard is the susceptibility of a place to any human and physical risk. In this case, we look at flood hazard as all the areas that are at risk of flood occurrence. The concept of flood hazard would be more appropriate to include localized flooding due to inadequate drainage, flooding from small streams, flooding in urban areas located on major river banks and urban areas experiencing coastal flooding (Benjamin, 2008).

\section{Flood Vulnerability and Resilience}

The term vulnerability refers to the tendency of exposed elements such as humans, their livelihoods, and assets when affected by hazards to suffer adverse effects. It is often determined by the physical, social, economic, environmental conditions and circumstances of a community or 
system that make them susceptible to the damaging effects of a hazard (UNISDR, 2009). Therefore, everyone may be exposed to a hazard in a certain area, but some social groups may respond better to emergencies (Steinführer et al., 2008).

Vulnerability and its various dimensions of measurements (physical, social, environmental and economic) are dynamic, with change in time and space and depend on the level of exposures and the potential hazards. With the issue of climate change in view, extreme hazards events and the continuous growing exposures through urbanization are expected to increase the level of vulnerability in many cities on the world (IPCC, 2007).

Direct measurement of vulnerability is not likely, an indicator is used to quantify the condition of a system as an essential characteristic (Balica et al., 2012). Gomez (2001) noted that indicators should focus on quantifiable and understandable small aspects of a system and give people a sense of a bigger picture. Indicators are input data that can be used to decide flood vulnerability of a region. Considering specific indicators can help to assess the systems vulnerability, which can lead to identifying actions needed to decrease the vulnerability (Balica et al., 2012). Societies are vulnerable to floods based on three main factors: exposure, susceptibility and resilience, which are explained below. In this study, it has been assumed that, the study area is vulnerable to flood as a result of these three factors.

Valuables such as infrastructure, goods, cultural heritage, and mostly people are exposed to flood as they are present at the location where the floods occurred. This factor extends to humans and their properties, which are positioned in flood risk areas. Messner and Meyer (2005) explained that the indicators of exposure supply certain facts about hazardous effect on the present elements at risk. Exposure is a necessary, but not a sufficient determinant of risk. Therefore, it is possible to be exposed to a hazard but not be vulnerable. For example, a person can live in a floodplain but have sufficient means to modify the building structure to mitigate potential losses (Cardona et al., 2012). Thus, the management of flood risk calls for a better understanding of vulnerability.

There are other concepts relating flood and its consequences. The concept of susceptibility explains how a system can be harmed potentially and the existing abilities to diminish the level of the damage. Smit and Wandel (2006) established that the vulnerability of any system is a function of the exposure and the susceptibility of that system to any hazardous event. Balica et al. (2009) discussed that susceptibility is mostly related to social aspect of flood damage and the system characteristics such as awareness and preparedness of people about the risk they live with. This study views susceptibility as elements exposed within a system and the probability of these elements harmed when a flood occurs i.e. elements that are exposed at the time of flood and the likelihood of these elements been affected.

De Bruijn (2005) expressed resilience as the system capability to resume from floods. Resilience can also be defined as the system capacity to re-achieve its balance after a reflex into a perturbation. Galderisi et al. (2005) argued that the resilience is a society or a system capacity to adapt itself to any change by resisting and modifying itself, to maintain or gain an acceptable level of structure and functioning. Pelling (2003) also explained this factor as any system or community ability to adjust to threats or mitigate the hazardous event damage.

The term resilience expands on vulnerability and may be viewed as the qualities the ability of a system, community or society exposed to hazards to resist, absorb, accommodate, adapt to, transform and recover from the effects of a hazard in a timely and efficient manner, including through the preservation and restoration of its essential basic structures and functions through risk management (UNISDR, 2009). Gallopin (2006) points out that while vulnerability can be seen as a fairly static concept, resilience is dynamic in nature. It contains uncertain feedback loops and interaction effects, changing with internal conditions, external forces, and with the community's ability to respond to floods. In this study, resilience is defined as the ability of a system to cope or adapt to the effect of floods.

Arguably, the rate of flood occurrence in recent times has been unprecedented. With 70 million people globally exposed to flooding every year, and more than 800 million living in flood 
prone areas (Peduzzi et al., 2009), climate change with more frequent and severe rainfall events, sea level rise, rapid population growth and urbanization, the rate of development on floodplains, the level of awareness of flood risk and the ineffectiveness of efforts towards tackling flooding in many places are factors of concern (Raaijmakers et al., 2008).

In many African countries like Nigeria, flooding has impoverished hundreds of thousands of people through displacement from homes and loss of tangible properties (Action Aid, 2006). In Nigeria, flooding and means of addressing its challenges are critical issues (Obeta, 2014). Evidently, the country has experienced devastating floods which has affected millions of people and caused fiscal losses amounting to billions of US dollars (NEMA 2013). These hazards were generally linked to poor urban planning and climate change especially in increased frequency and intensity of rainfall (Action Aid, 2006; Adeloye 2011).

Quite a number of researches have been carried out in Nigeria in assessing the exposures and vulnerability of the Nigerian settlements to flooding. Onwuteaka (2014) applied GIS and digital elevation model to simulate extent of flooding exposure in the coastal areas and the vulnerability to sea level rise. At the varying sea elevation, the expected surface areas capable of being impacted by flood were identified for the modeled flooding from the sea level rise.

Nwilo et al. (2012) assessed the physical vulnerability of some communities in Adamawa State, Northern part of Nigeria by modeling the flood inundation level using Remote sensing and Cellular Automaton Evolutionary Slope and River (CAESAR) software. The output of the model shows the water heights and possible settlements at risk within the flood prone areas of the inundation. Hence, an attempt to examine the physical vulnerability of the communities was further analyzed by Mayomi et al. (2013) using Geographic Information Systems (GIS). Their study made use of Global Positional Systems (GPS) measurement to map all the settlements and integrated with the terrain model of the area to determine those areas that are within the flood plain.

Vulnerability of some coastal communities in Lagos was examined by Adelekan (2009) using both quantitative and qualitative methods by analyzing data acquired from questionnaires, interviews and focus group discussion. The study also analyzed the impacts of and vulnerability to flooding within the coastal communities based on their level of income. The results asserted that most affected people in the area are the non-employed and less income people.

In an attempt to assess the vulnerability of the exposures to flood within Ala river basin in Nigeria, Vulnerability of the affected villages and towns during 2012 flood was mapped by Ojigi et al. (2013) using remote sensing and GIS. Flood extent and the vulnerable cities and villages were identified using buffering techniques. A non-parametric approach to delineate floodplain in

Gwagwalada town was adopted by Oyatayo et al. (2014) using topographic data, quick bird imagery and GPS data. Level of vulnerability of the town was determined and classified by the elevation in meter above sea level (m.a.s.l), which revealed a gradual build-up into the floodplain area of the town.

The study carried out by Enaruvbe and Yesuf (2012) in Delta State, as part of flood risk analysis following the devastating 2012 flood event, made use of GIS and ASTER DEM to delineate the floodplain based on field survey in the affected areas. Flood affected and vulnerable zones were mapped using buffering tools in GIS environment. Geospatial techniques were applied by Nkeki et al. (2013) to map vulnerable zones within Niger-Benue basin. MODIS time series image, integrated with the digital elevation model were used to extract the flood plain within the basin. Various cities, states and communities that are vulnerable to flood hazards were mapped using population data; this was integrated with the flood hazards map to delineate the population at risk of flood disaster in the basin using overlay analysis.

In Samagba area of Bayelsa State, Mmom and Akpi (2004) determined the vulnerability of the communities to flooding using elevation and remote sensing image data. Analytical Hierarchical Process (AHP) was adopted to assign weights to various contributory factors such as elevation, land use, rivers and roads to determine the most vulnerable zones within the area; these were integrated using re-classification and overlay analysis in GIS to determine the flood affected areas. 
Analysis done by Ejenma et al. (2014) over River Kaduna utilized DEM to delineate flow accumulation of the rivers; this was assumed to be the floodplain and classified to various degrees of severity and overlaid on Lands at ETM to delineate vulnerable areas within the area.

In contrast to the qualitative physical vulnerability studies by the earlier authors, Ajibade et al. (2013) examined the socio-economic impacts of flash flood on women in Nigeria using Lagos State as a case study. The authors utilized both questionnaires and focused group survey to understand the impacts of flood on lives, livelihoods and health. Their results revealed a nongender biased impacts, however, a more severe impacts recorded within low-income neighborhood than those in high income neighborhood.

A post July, 2007 flood survey carried out by Adelekan (2011) to examine the vulnerability of the urban dwellers in Abeokuta, Ogun State in terms of their awareness and preparation for such events. The study, which made use of responses of the administered questionnaires showed a general lack of early warning systems in the study area and affirmed the high risk to flooding due to lack of pre-flood information and preparation.

Vulnerable and exposed population to flooding in River Ogun, Ogun-State was analyzed by Sobowale and Oyedepo (2013) by modelling rain-runoff to generate flood inundation model. The study identified over 1.4 million inhabitants that were at risk in the area, with suggested possible adaptation measures for future occurrences.

Studies on exposure and vulnerability to flooding in Nigeria is still at infant stage and would require more advanced studies to bridge the gap that exists, especially when compared with the developed countries. This research focuses on considering the factors responsible for flood incidence, the frequency of flood incidence in Ibaji LGA and the vulnerability of the study area. Resilience and coping capacity is dependent on the awareness about the disaster.

\section{METHODS OF DATA COLLECTION}

The methods used for data collection in this research included field observation, questionnaire administration and collection of secondary data from relevant agencies. Satellite imagery was also obtained from the United States Geological Survey (USGS) this was used to generate the land-use map of the study area Rainfall data was sourced from Nigeria Meteorological Agency (NIMET) Kogi State; this was used to ascertain the mean monthly rainfall distribution pattern in the study area over a period of 15 years. Rainfall data obtained from the Center for Hydrometeorology and Remote Sensing was used to generate rainfall distribution map of Ibaji LGA. The following applications were accessed to give wide understanding of the magnitudes of flooding in the study area.

Image Processing: Satellite imagery of Ibaji LGA was enhanced to improve the visualization of features, geometric and radiometric corrections were Orto-rectified. The images obtained were in different layers and band 4, 3,2 was layer stacked and subset the area of interest using ENVI 5.1 Software.

Generation of Land Use Map: Landsat 7 Imagery of Ibaji LGA (30m) was orto-rectified and there was no need for any geometric and radiometric corrections. The area of interest was clipped out of the imagery. Supervised classification was then carried out into five classes (water body, vegetation, farmland, bare land and built-up area). This is to enable the researcher ascertain the land use pattern in the area and the areas that are susceptible to flood occurrence as well as how the land use pattern influences flood occurrence in the study area.

Generation of Slope and Elevation Maps: The Digital Elevation Model (DEM) of Ibaji LGA was created from Digital Elevation Model (DEM) of ArcGIS. This was used to produce elevation map and slope map of Ibaji LGA using spatial analysis tools on ArcGIS. This is to determine the influence of slope and elevation in the occurrence of flood within the study area.

Generation of Drainage Density Map: The drainage density Map of Ibaji Local Government Area was generated from the Shuttle Radar Topographic mission (SRTM). Ibaji LGA was clipped 
out of Shuttle Radar Topography Mission (30m) of SRTM Nigeria 2014. The drainage density was analyzed using the Hydrology Tool box of Spatial Analyst Tools on ArcGIS software..

Generation of Soil Map: The soil map of Nigeria was scanned and imported into ArcGIS environment where it was geo-referenced using UTM Zone 32 North with datum WGS 1984. Ibaji Local Government Area was subset from the soil map of Nigeria and the soil types of Ibaji LGA were digitized.

Generation of Rainfall Map: The mean annual rainfall for 2003 to 2018 of Ibaji Local Government Area was used to determine the pattern of rainfall. Rainfall data of Kogi State was derived from the Center for Hydrometeorology and Remote Sensing as a raster file, with a resolution of $4 \mathrm{~km} \times 4 \mathrm{~km}$. points data where then created in ArcGIS with cell width and height of $4 \mathrm{~km}$ the values each cell in rainfall data downloaded was extracted using the extract multi values to point tool in Spatial Analyst tool box. Then the extracted rainfall data was interpolated using the Spline Analyst tool box.

Steps Used in Deriving Criterion Weight Using AHP: The relationship between the six causative thematic map and their attributes were derived using Analytic Hierarchy Process (AHP) to determine the most potent factor responsible for floods in Ibaji LGA of Kogi State. The methodology used for deriving their weights involved the following steps as developed by Saaty, 1980: Step 1: Defining the problem clearly and decomposing it into various thematic layers containing the different features/classes of the individual themes so that they form a network of the model (Abah, 2014). Step 2: Generating Pair-wise comparison matrices, the relative important values are determined with Saaty's 1-9 scale (Table 3.2) where a score of 1 represents equal importance between the two attributes, and a score of 9 indicates the extreme importance of an attribute compared to the other one (Abah, 2014).

\section{RESULTS AND DISCUSSION}

\section{Incidence of flood in Ibaji LGA}

There is an increasing treat to lives and properties as a result of flood in many urban and rural communities within Nigeria (Olanrewaju and Fadiro, 2003). Prior to 2012, flood incidence was not a subject of major concern in Ibaji LGA. The unprecedented flood incidence in 2012 ravaged Ibaji LGA and other parts of Kogi State destroying farmlands, homes and villages (Jacob, 2014). According to KOSEMA, Flood incidence in Ibaji occurs mainly in the rainy season and due to the high intensity of prolonged rainfall. The communities that are mostly affected by flood in the study area are in close proximity with rivers and lie within low elevation in the study area.

\section{Factors Influencing Floods in Ibaji Local Government Area}

The factors considered in this research were rainfall, elevation, slope, soil, drainage density and land cover. The classes of the factors were further weighed using Saaty's scale of pair-wise comparison and reclassified using reclass tool on ArcGIS to identify the major factors influencing floods. The combined weights for all the factors are shown in Table 1.

Table 1. Combined Weight for Flood Causative Factors

\begin{tabular}{|c|c|c|c|c|c|c|c|}
\hline & Rainfall & $\begin{array}{c}\text { Drainage } \\
\text { Density }\end{array}$ & Slope & Elevation & LULC & Soil & $\begin{array}{c}\text { Weight } \\
(\%)\end{array}$ \\
\hline Rainfall & 1 & 2 & 2 & 1 & 2 & 2 & 24.4 \\
\hline Drainage Density & 0.5 & 1 & 2 & 1 & 1 & 2 & 17.9 \\
\hline Slope & 0.5 & 0.5 & 1 & 2 & 3 & 1 & 18.5 \\
\hline Elevation & 1 & 1 & 0.5 & 1 & 2 & 2 & 17.4 \\
\hline LULC & 0.5 & 1 & 0.33 & 0.5 & 1 & 2 & 11.8 \\
\hline Soil & 0.5 & 0.5 & 1 & 0.5 & 0.5 & 1 & 9.9 \\
\hline
\end{tabular}

Consistency Ratio CR: 0.076 


\section{Areas Vulnerable to Flood in Ibaji}

This section used the results of the combined pair-wise comparison carried out for the six flood causative factors on Table 1 based on Saaty's Fundamental scale of pair-wise comparison and generated flood vulnerability map. To determine vulnerability level of communities, the factors weight from Analytical Hierarchy Process (AHP) were overlaid using the weighted sum in ArcGIS spatial tool to produce the flood vulnerability map of five levels (very low vulnerable areas, low vulnerable areas, moderate vulnerable areas, high vulnerable areas and very high vulnerable areas) as presented on Figure 3.

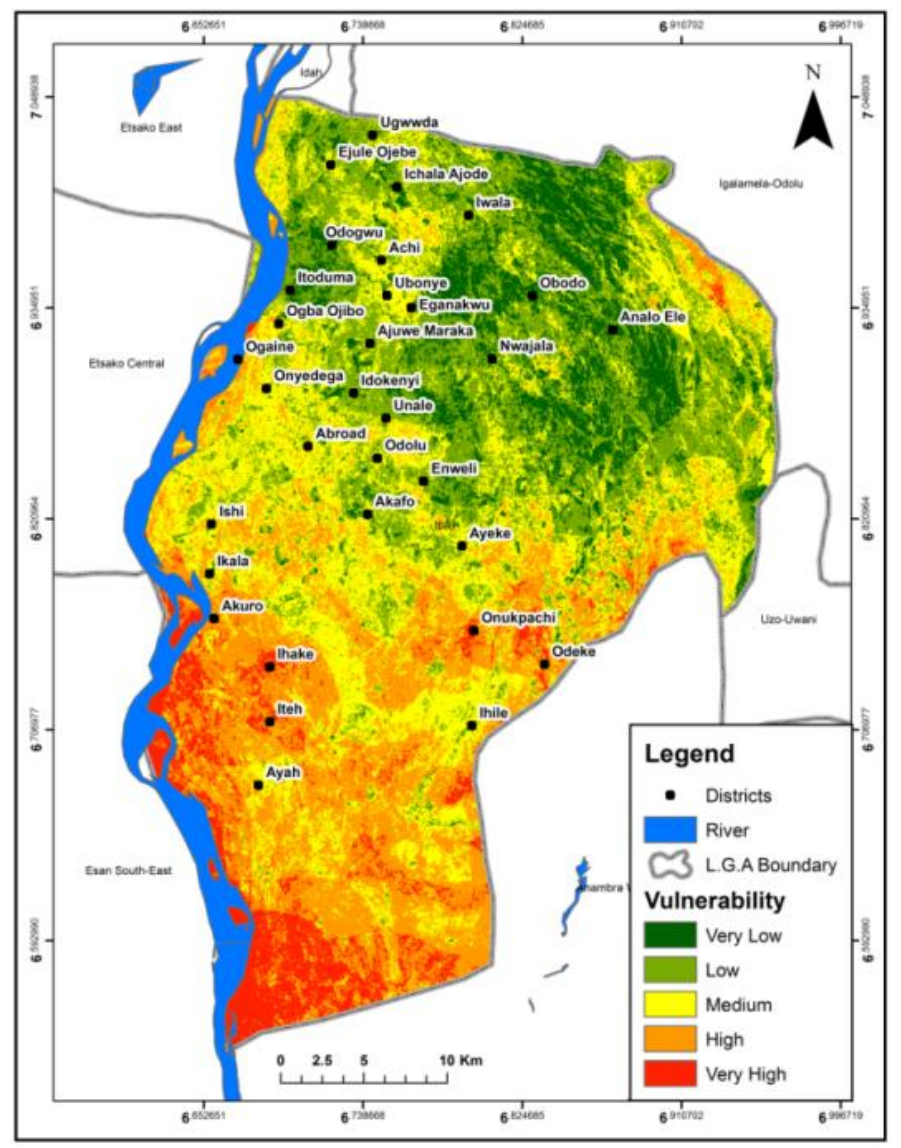

Figure 3. Flood Vulnerability Map of the Study Area

The results of the analysis carried out, showed that some communities (Odogwu, Obodo and Analo Ele) are found to be within the very high vulnerable areas which means that there is high tendency for those communities to be more liable to flooding than other communities. In the results some communities (Odolu, Ayeke and Unale) are also found within the high vulnerable areas which means that the possibility of those communities to be more liable to flooding is high than those within moderate, low and very low vulnerable areas. The communities that are within moderate vulnerable areas are; Ogba-Ojigbo and Onyedega while those within the low Vulnerable areas are; Odolu, Unale and Ayeke. The communities that are least vulnerable (very low vulnerable) are; Odogwu, Obodo, Analo Ele.

From this research, it was observed that most of the communities that are vulnerable are located close to bank of River Niger and are characterized with low elevation and slope. The 
observation of this study affirms Isma'il and Iyortim (2013) that areas that lie beside a river may not be liable to flood if it is at a great height while areas that lie far away may experience floods if the intervening land is flat, gentle sloping or if the area lies in a depression.

\section{CONCLUSIONS}

The result of this study revealed that rainfall has the greatest effect on flood in Ibaji LGA, other factors such as elevation, slope, drainage density, Land Use / Land cover and soil are significant in the occurrence of flood in Ibaji LGA. The findings of this research also established that flood is more likely to occurs in areas where the effect of more than on factor is predominant for instance where there is high rainfall and at a low elevation and with a poor drainage is more likely to be flooded than areas that experience high rainfall and have a high elevation and is well drained. There is no single factor responsible for the occurrence of flooding. Flood is a product of the interplay of several factors which all vary in the level of impact they have in the occurrence of the phenomenon.

The extent of damage caused by floods is on the one hand dependent on the extent, depth and duration of flooding, and the velocities of flows in the flooded areas which are dependent on the factors examined in this research work (Rainfall, Slope, Elevation, Drainage, Soil and LandUse). On the other hand it is dependent on the vulnerabilities of economic activities and communities. The huge socioeconomic effects of flood have a negative effect on the economy, agricultural activities, Health, Infrastructure and education of the communities affected. Displacement from one's home, loss of property, loss of livelihoods, decreased levels of security in the aftermath of floods and in temporary shelters, and disruption to business and social affairs are consequences of floods and these can cause lasting impact on the affected communities.

Based on the findings of this research work, measures to minimize the adverse effect of flood in the study area are suggested, as a result, the following recommendations are made.

1. A more comprehensive flood control and preventive measure paying particular attention to flood prone areas should be adopted and integrated in plans for States, Local Governments and Villages.

2. Existing flood plans and control measures should be reviewed to meet present realities and challenges.

3. Public enlightenment should be emphasized on the dangers associated practices that will affect the environment and create risk to individuals; and

4. Further studies on post flood assessment should be encouraged to understand the peculiarities of flood events.

\section{REFERENCES}

Abah, G.O. (2014). Rainfall Variability in Northern Nigeria, Implication for National Planning Ph.D, Thesis, Department of Geography, Ambrose Ali University, Ekpoma, Edo State, Nigeria

Action Aid (2006). Climate Change, Urban Flooding and the Rights of the Urban Poor in Africa: Key Findings from Six African Cities, London: Action Aid International.

Adelekan, I. O. (2010). Vulnerability of poor urban coastal communities to flooding in Lagos, Nigeria. Environment and urbanization, 22(2), 433-450.

Adelekan, I. O. (2011). Vulnerability assessment of an urban flood in Nigeria: Abeokuta flood 2007. Natural Hazards, 56(1), 215-231.

Ajibade, I., McBean, G., \& Bezner-Kerr, R. (2013). Urban flooding in Lagos, Nigeria: Patterns of vulnerability and resilience among women. Global Environmental Change, 23(6), 1714-1725.

Atoyebi, T.R. (2013). Frequency Analysis of Maximum Daily Rainfall for Selected Towns in North-Central Nigeria. Hydrology and Water Resource, 9(3), 45.

Balica, S. F., Douben, N., \& Wright, N. G. (2009). Flood vulnerability indices at varying spatial scales. Water science and Technology, 60(10), 2571-2580.

Balica, S. F., Wright, N. G., \& Van der Meulen, F. (2012). A flood vulnerability index for coastal cities and its use in assessing climate change impacts. Natural hazards, 64(1), 73-105. 
Benjamin, M. A. (2008). Analysing urban flood risk in low-cost settlements of George, Western Cape, South Africa: Investigating physical and social dimensions (Master's thesis, University of Cape Town).

Birkmann, J. (2006). Measuring vulnerability to promote disaster-resilient societies: Conceptual frameworks and definitions. Measuring vulnerability to natural hazards: Towards disaster resilient societies, 1(9), 3-7.

Cardona, O. D., Van Aalst, M. K., Birkmann, J., Fordham, M., Mc Gregor, G., Rosa, P., ... \& Thomalla, F. (2012). Determinants of risk: exposure and vulnerability. In Managing the risks of extreme events and disasters to advance climate change adaptation: special report of the intergovernmental panel on climate change (pp. 65108). Cambridge University Press.

De Bruijn, K. M. (2004). Resilience indicators for flood risk management systems of lowland rivers. International Journal of River Basin Management, 2(3), 199-210.

Disaster Management Support Group (2001). The Use of Earth Observation Satellites for Hazard Assessment and Scenarios, Committee on Earth Observation Satellites Disaster Management Support Group, USA: NOAA, Department commerce.

Ejenma, E., Sunday, V. N., Okeke, O., Eluwah, A. N., \& Onwuchekwa, I. S. (2014). Mapping flood vulnerability arising from land use/land covers change along river Kaduna, Kaduna State, Nigeria. J. Humanit. Soc. Sci, 19, 155-160.

Enaruvbe, G. O., \& Yesuf, G. U. (2016). Spatial analysis of flood disaster in Delta State, Nigeria. Ife Research Publications in Geography, 11(1), 52-58.

Galderisi, A., Ceudech, A., \& Pistucci, M. (2005, December). Integrated vulnerability assessment: The relevance "to" and "of" urban planning. In Proceedings (CD format) of the 1st ARMONIA Project Conference (pp. 5-6).

Gallopín, G. C. (2006). Linkages between vulnerability, resilience, and adaptive capacity. Global environmental change, 16(3), 293-303.

Gomez, G. (2001). Combating Desertification in Mediterranean Europe: Linking Science with Stakeholders, contract EVK2-CT-2001-00109. King's College, London.

Herman, G. V. (2009). Omul şi modificările antropice din Câmpia Someşului [The man and anthropogenic changes in Somes Plain], Editura Universităţii din Oradea, 227 pag., ISBN 978-973-759-981-0, Oradea.

Herman, G. V. (2010). Using Geographical Information (GIS) System for Management of Flood Risks in the Somes Plain, in Cross-Border Partnership with Special Regard to the Hungarian - Romanian - Ukrainian Tripartite Border, Book Editors Ioan Horga, Istvan Suli Zakar, Publishing House University of Debrecen Press, p. 175 - 179.

Hula, M. A., \& Udoh, J. C. (2015). An assessment of the impact of flood events in Makurdi, Nigeria. Civil and Environmental Research, 7(10), 53-60.

Intergovernmental Panel on Climate Change (IPCC) (2007). Climate Change Impacts, adaptation and Vulnerability, Contribution of Working Group II to the Fourth Assessment Report of the IPCC Assessment. Report, Summary for Policymakers. http://www.icpc.ch/pdf/assessment-report/ar4/wg2/ar4-wg2-spm.pdf

Isma'il, M., \& Saanyol, I. O. (2013). Application of remote sensing (RS) and geographic information systems (GIS) in flood vulnerability mapping: case study of River Kaduna. International Journal of Geomatics and Geosciences, 3(3), 618.

Jacob, A. (2014). Ibaji: The Land and the People; Onaivi Printing and Pub. Co. Ltd. Lokoja Nigeria, ISBN 978-079-295-3.

Jeb, D. N., \& Aggarwal, S. P. (2008). Flood inundation hazard modeling of the River Kaduna using remote sensing and geographic information systems. Journal of Applied Sciences Research, 4(12), 1822-1833.

Karmakar, S., Simonovic, S. P., Peck, A., \& Black, J. (2010). An information system for risk-vulnerability assessment to flood. Journal of Geographic Information System, 2(03), 129-146.

Kogi State Emergency Management Agency (KOSEMA) (2007). Report on the Flood Disaster in Ibaji Local Government, Kogi State, Lokoja: Office of the Secretary KOSEMA.

Kreibich, H., Seifert, I., Merz, B., \& Thieken, A. H. (2010). Development of FLEMOcs-a new model for the estimation of flood losses in the commercial sector. Hydrological Sciences Journal-Journal des Sciences Hydrologiques, 55(8), 1302-1314.

Mayomi, I., Dami, A., \& Maryah, U. M. (2013). GIS based assessment of flood risk and vulnerability of communities in the Benue floodplains, Adamawa State, Nigeria. Journal of geography and geology, 5(4), 148-160.

Meyer, V., \& Messner, F. (2005). National flood damage evaluation methods: a review of applied methods in England, the Netherlands, the Czech Republik and Germany.

Mmom, P. C., \& Ayakpo, A. (2014). Spatial analysis of flood vulnerability levels in Sagbama Local Government Area using geographic information systems (GIS). International Journal of Research in Environmental Studies, 1, 1-8.

Moel, H. D., Asselman, N. E. M., \& Aerts, J. C. J. H. (2012). Uncertainty and sensitivity analysis of coastal flood damage estimates in the west of the Netherlands. Natural Hazards and Earth System Sciences, 12(4), 1045-1058.

Mukhopadhyay, S. (2010). A geo-environmental assessment of flood dynamics in lower Ajoy River inducing sand splay problem in Eastern India. Ethiopian Journal of Environmental Studies and Management, 3(2).

National Emergency Management Agency (NEMA) (2012). Flood: more than 25, 000 displaced in Benue as many communities remain adamant, Accessed online on the $10^{\text {th }}$ of December 2015 via http://www.nema.gov.ng/emergency-zones/floods.aspx

Nkeki, F. N., Henah, P. J., \& Ojeh, V. N. (2013). Geospatial techniques for the assessment and analysis of flood risk along the Niger-Benue Basin in Nigeria. Journal of Geographic Information Systems, 5, 123-135.

Nwilo, P. C., Olayinka, D. N., \& Adzandeh, A. E. (2012). Flood modelling and vulnerability assessment of settlements in the Adamawa state floodplain using GIS and cellular framework approach. Global Journal of Human Social Science, 12(3), 11-20. 
Obeta, M. C. (2014). Institutional approach to flood disaster management in Nigeria: need for a preparedness plan. Current Journal of Applied Science and Technology, 4575-4590.

Ojigi, M. L., Abdulkadir, F. I., \& Aderoju, M. O. (2013, April). Geospatial mapping and analysis of the 2012 flood disaster in central parts of Nigeria. In 8th National GIS Symposium. Dammam. Saudi Arabia (pp. 1067-1077).

Olajuyigbe, A. E., Rotowa, O. O., \& Durojaye, E. (2012). An assessment of flood hazard in Nigeria: The case of mile 12, Lagos. Mediterranean Journal of Social Sciences, 3(2), 367-367.

Olanrewaju, D. O., \& Fadairo, G. (2003). Flooding as an Induced Environmental Problem-A case study of Ala River in Akure, Nigeria. Journal of the Nigerian Institute of Town Planners, 16(1), 85-95.

Onwuteaka, J. (2014). GIS modeling of flooding exposure in Nigerian coastal areas from sea level rise. J. Environ. Earth Sci, 4, 81-94.

Oriola, E. O. (1994). Strategies for combating urban flooding in a developing nation: A case study from Ondo, Nigeria. Environmentalist, 14(1), 57-62.

Oyatayo, K. T., Uwazuruonye, J., Andesikuteb, A., Tata, H., Abimiku, E. S., Shaba, H. A., ... \& Jidauna, G. (2014). Non parametric modeling of flood vulnerability: For sustainable growth and development of Gwagwalada, Federal Capital Territory, Nigeria. J. Environ. Sci. Policy Evaluat, 4, 15-23.

Peduzzi, P., Dao, H., Herold, C., \& Mouton, F. (2009). Assessing global exposure and vulnerability towards natural hazards: the Disaster Risk Index. Natural hazards and earth system sciences, 9(4), 1149-1159.

Pelling, M. (2003). The vulnerability of cities: natural disasters and social resilience. Earthscan.

Raaijmakers, R., Krywkow, J., \& van der Veen, A. (2008). Flood risk perceptions and spatial multi-criteria analysis: an exploratory research for hazard mitigation. Natural hazards, 46(3), 307-322.

Saaty, L.T. (1980). The Analytic Hierarchy Process, New York.

Smit, B., \& Wandel, J. (2006). Adaptation, adaptive capacity and vulnerability. Global environmental change, 16(3), $282-292$.

Sobowale, A., \& Oyedepo, J. A. (2013). Status of flood vulnerability area in an ungauged basin, southwest Nigeria. International Journal of Agricultural and Biological Engineering, 6(2), 28-36.

Steinführer, A. (2009). Recommendations for flood risk management with communities at risk. T11-07-14.

United Nation, UN (2003). Guidelines on participatory planning and management for flood mitigation and preparedness, 9(129): ill., Water resources series, 0082-8130, no. 82, United Nations: New York

United Nations Office of Disaster Risk Reduction, UNISDR (2009). Terminology on Disaster Risk Reduction, Geneva, Switzerland.

Ward, P. J., Renssen, H., Aerts, J. C. J. H., Van Balen, R. T., \& Vandenberghe, J. (2008). Strong increases in flood frequency and discharge of the River Meuse over the late Holocene: impacts of long-term anthropogenic land use change and climate variability. Hydrology and Earth System Sciences, 12(1), 159-175.

World Bank (2013). The world Bank: Working for a world free of poverty, Population (Total). Washington, DC: World Bank Group.

Submitted:

September 28, 2020
Revised:

April 20, 2021
Accepted and published online May 26, 2021 